\title{
Influence of Functional Feed Additive at the Basis of the Chankanay Deposit's Zeolite to the Intestinal Microbiocenosis of Broiler Chickens
}

\author{
A.Y. Slyamova, N.B. Sarsembayeva, A.E. Ussenbayev, and A.Y. Paritova
}

\begin{abstract}
This article presents the results of research of the influence of the functional feed additive at basis of the Chankanay deposit's zeolite to the intestinal microbiocenosis of broilers. Experiments were carried out from 2014 to 2015 at the vivarium of the Kazakh National Agrarian University. The objects of study were 40 chickens of "Smena-7" cross which were divided into two groups for 20 birds at the each. The first group chickens were fed by the basic diet and second group received the diet with adding $5 \%$ of feed additive. The research conducted for $\mathbf{4 2}$ days and it showed that functional feed additive had a positive effect on the broilers' intestinal microbiocenosis, i.e. significantly decreased the total number of pathogenic bacteria and yeast, as well as elevated levels of lactobacillus and bifidobacteria.
\end{abstract}

Key words - broilers, Chankanay deposit's zeolite, functional feed additive, intestinal microbiocenosis.

\section{INTRODUCTION}

Poultry industry in Kazakhstan is currently one of the most developed sectors of the livestock production.

According to the Kazakhstan official statistics in the $1^{\text {st }}$ July 2013 the number of birds of all kinds was about 34.5 million more than $60 \%$ of them were accounted in farms with appropriate material and technical base producing poultry products at the industrial scale [1], [2].

Currently, one of the main ways of increasing of productivity in the poultry industry is to find and use dietary supplements for feeding of birds. The high productivity of birds and animals, the maintenance of productive functions of the body, feed efficiency is now impossible without the inclusion into the diet of proper feed additives that provide the necessary level of nutrition [3].

In this regard the main trend of modern technology that improves feeding in poultry is finding, developing and implementing in the production of inexpensive, but effective feed additives [4].

One of the most promising sources of trends is the use of feed additives as natural zeolites [5].

Studies to determine the effectiveness of the inclusion of certain types of zeolites in poultry feed, primarily clinoptilolites and heulandites were conducted in many research institutions. The obtained results led to the introduction of zeolites as additives in the diets of laying hens and broilers. The efficiency of the use of zeolites depends on the kind of the tuff, its chemical composition and particle size, dose, diet composition, the species and age of poultry [6].

Basically in feeding livestock and poultry are used three types of zeolites - clinoptilolite, mordenite and heulandites. However, the use of zeolites of some fields in low doses did not reveal their positive effects on the body of animals [7].

Functional feed additives promote active colonization of bifidobacteria and lactobacilli group at an earlier age and also normalize a digestion. Using a variety of biologically active feed additives could improve the intestinal microbiocenosis and digestion, it might to increase productivity of birds and reduce the cost of feed [8], [9].

The main goal of the research was to study the influence of functional feed additives based on Chankanay deposit's zeolite into broilers intestine for the subject of microbiocenosis.

\section{MAterials AND Methods}

The experimental work was carried out in 2014 at the vivarium of the Kazakh National Agrarian University and at the Laboratory Antibacterial Biotechnology. The objects of study were 40 broiler chickens of "Smena-7" cross from "Allele-Agro" poultry farm's hatchery. The birds were housed in cages. The housing conditions were compatible with the existing technological requirements. To conduct the study two groups of chickens - experimental and control - were formed (20 birds in each) on the principle of analogues. Feeding chickens included three - the start (1 - 14 days), growth (15 28 days) and finishing (from 29 to 42 per day) - periods according instructions of the industrial poultry farm scheme "Allele-Agro" with commercial basic diet (BD). The chickens were allowed to have free access to feed and water. Chickens in the control group received the $\mathrm{BD}$. Into $\mathrm{BD}$ of the experimental group was daily adding $5 \%$ of the functional feed additive based on zeolite from the first feeding day.

The study scheme is presented below (Table I).

\begin{tabular}{llll}
\multicolumn{4}{c}{ TABLE I: STUDY SCHEME } \\
\hline \hline Indicators & Starter & Growth & Finish \\
\hline Control group (BD) & $300 \mathrm{~g}$ & $400 \mathrm{~g}$ & $500 \mathrm{~g}$ \\
Experimental group & $285 \mathrm{~g}+15 \mathrm{~g}$ & $380 \mathrm{~g}+20 \mathrm{~g}$ & $475 \mathrm{~g}+25 \mathrm{~g}$ \\
(BD $+5 \%$ feed & & & \\
additive) & & & \\
\hline \hline
\end{tabular}

Before feeding zeolite was grinded to particles size 0.5-3.0 $\mathrm{mm}$. Experiment's scheme depended on the purpose of the 
experiment and subsequently will be reflected in the description of the relevant research results.

Microbiological tests were taken from the contents of small and large intestines of the randomly selected and killed five chickens in the each group at the first, $7^{\text {th }}, 20^{\text {th }}$ and $42^{\text {nd }}$ days. Study of the intestinal microbiota was performed by quantitative group analysis.

The intestinal tract was separated immediately after slaughter. The samples of intestine contents $(1 \mathrm{~g})$ were transferred under aseptic conditions and diluted with saline solution (1:10) for determination of specific quantitative microflora composition [10]. After dilution, $100 \mu \mathrm{l}$ of each sample was planted onto the following media: Endo-agar for E. coli, Sabouraud-agar for fungi, MPA-agar for Streptococcus, Yolk-salt-agar for Staphylococcus, Vismut sulfite agar and Ploskirev agar for Salmonella and Shigella spp., Blaurokk-media for bifidobacteria and Lactobacillus spp. They were incubated at $37^{\circ} \mathrm{C}$ for $24-72 \mathrm{~h}$. After the incubation the colonies on the culture media were counted and the numbers of viable colony forming units (CFU) per $\mathrm{g}$ were calculated. The identification was conducted according to Bergey's Manual of Determinative Bacteriology [11] by morphological, cultural, physiological and biochemical properties of microorganisms.

The significance of difference among the groups was determined by one-way analysis of variance (ANOVA) and ttest. Differences were considered significant at $\mathrm{p}<0.01$.

The study was approved by the Local Ethical Committee of the Kazakh National Agrarian University, in accordance with the ethical standards of Principles of Animal Care.

\section{RESUlts AND DiscUSSION}

The results of the experiment showed that dynamics of formation of the whole microbiocenosis had some differences at chickens of the control and experimental groups. So, significant differences were revealed in the intensity of colonization of the intestinal biocenosis that was depending from the broilers' age of the both groups (Figures 1,2).

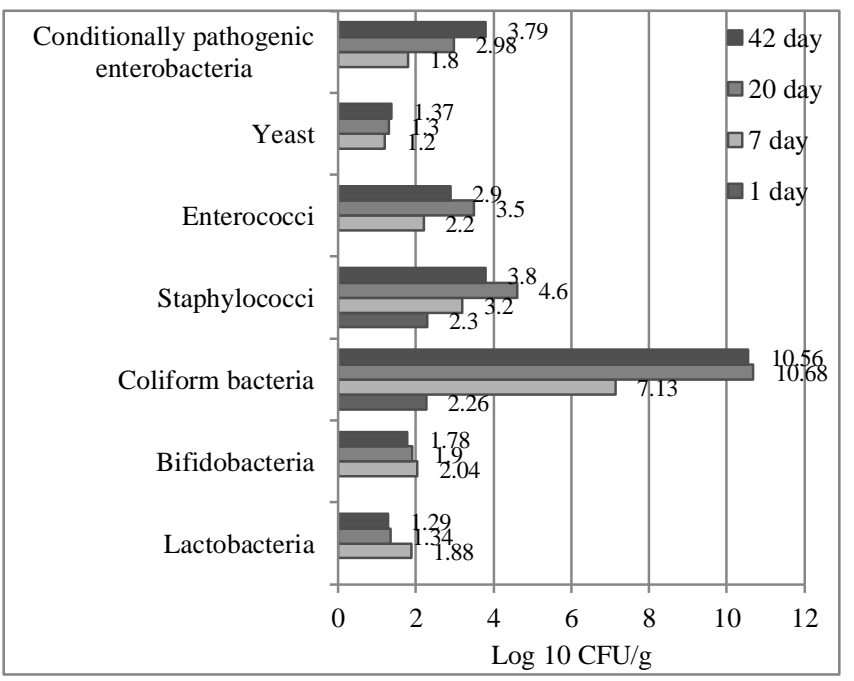

Fig. 1. Status of intestinal microbiota of control group broiler chickens at different ages, $\log _{10} \mathrm{CFU} / \mathrm{g}$
In day-old chicks microflora consists mainly of Escherichia coli. Nevertheless, at the samples of seven days old chickens we observed the population of the intestinal bacteria included E.coli, lactic acid bacteria and bifidobacteria.

The number of bifidobacteria in experimental group decreased with respect to the data of 7-day-old on $2.84 \log _{10}$ $\mathrm{CFU} / \mathrm{g}(\mathrm{p}<0.05)$ greater than that of the control counter parts. 20 days-old chicks of the control group had significant decrease of the of lactobacilli number with $4.8 \log _{10} \mathrm{CFU} / \mathrm{g}$ $(\mathrm{p}<0.01)$ to $1.34 \log _{10} \mathrm{CFU} / \mathrm{g}(\mathrm{p}<0.05)$ than in experimental group of chickens.

So chickens of this age in the experimental group had active colonization of intestine by bifidobacteria and lactobacilli. It could be suggested that their growth suppressed E.coli, the amount of which was at the level $10.68 \log _{10}$ $\mathrm{CFU} / \mathrm{g}(\mathrm{p}<0.01)$. On the other hand it can be attributed the fact that the contents of the intestine there was an increase in the number of staphylococci in control group (4.6 $\log _{10}$ $\mathrm{CFU} / \mathrm{g}$ ) than in the experimental group.

The number of conditionally pathogenic enterobacteria in the control group was the first day $1.8 \log _{10} \mathrm{CFU} / \mathrm{g}(\mathrm{p}<0.01)$ and in the experimental group it was $1.1 \log _{10} \mathrm{CFU} / \mathrm{g}$ $(\mathrm{p}<0.01)$. Yeast also goes to the down turn in samples from the experimental group compared to controls in all periods of growth of broiler chickens.

It is known that the bacterial composition of the intestinal microflora of any kind of livestock and poultry is unstable. At the moment of hatching the intestine of chickens is sterile and after hatching it is being populated by environmental microorganisms [12]. Therefore, the providing for the rapid and valuable formation of microflora composition of the intestinal tract in nestlings is a main problem of healthy poultry production [13].

Every microorganism group in the intestinal tract performs its function. Bifidus bacteria generate organic acids and create unfavourable conditions for reproduction of pathogens [14].

Escherichia coli, being strict anaerobes, use oxygen and create favourable conditions for other bacteria, and secrete colicins, which inhibit the growth of pathogenic microorganisms [15].

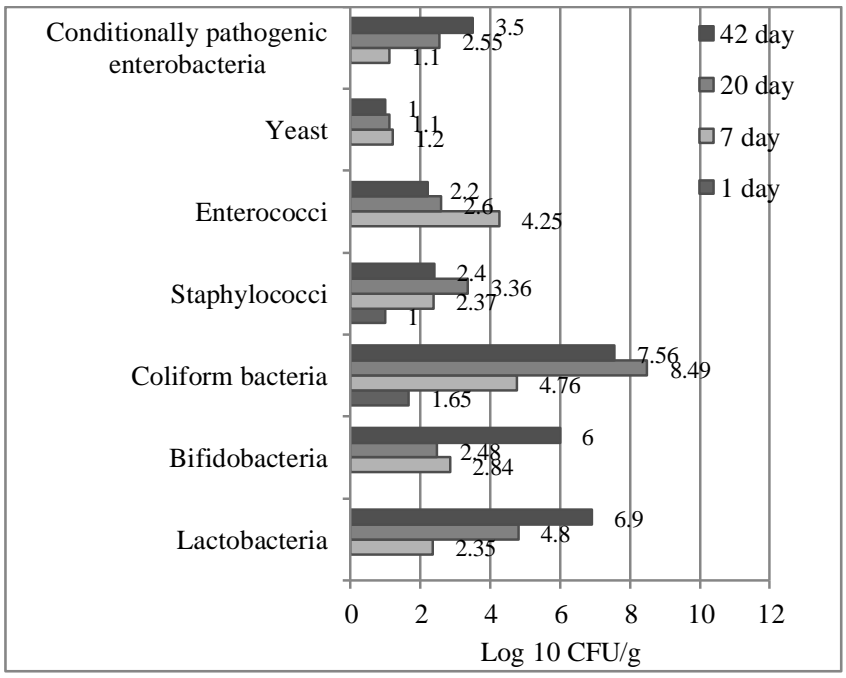

Fig. 2. Status of intestinal microbiota of broiler chickens of the experimental group at different ages, $\log _{10} \mathrm{CFU} / \mathrm{g}$ 
The composition of forage influences birds' health and their resistance to pathogenic microflora [16], [17]. The intestinal microbial associations are substrate-specific and therefore they depend on nutrient presence in the occupation zone. It is known that the basic microorganisms for animals or birds are facultative and strict anaerobe bifidobacteria, Lactobacillus and lactate-fermentation bacteria, and Bacteroides [18] - [20].

In poor hygienic conditions birds that were fed the poor quality food and had unbalanced feeding tend to have unbalanced intestinal microflora: the active propagation of pathogenic bacteria and repression of representatives of the "normal" microflora with all the following negative consequences [21], [22].

Under natural conditions, the establishment of microflora in the digestive tract of warm-blooded animals soon after birth is an inevitable process. However, despite the crucial role of the microflora in the life of the microorganism, today there is no uniform classification of it. Many researchers use the intestine fundamental criteria for the quantitative aspects of the microflora, dividing them into the main, and the concomitant residual. Therefore, the primary objective is further to ensure and maintain the gut microflora of poultry at its normal level [23].

Results of this research have found that the functional feed additive based on Chankanay deposit zeolite has a positive effect on the broilers' intestinal microbiocenosis, reducing the content of yeast and staphylococci. The process of suppressing the pathogenic bacteria occurs apparently due to the fact that this feed additive possesses antibacterial properties. At the same time reducing background of pathogenic bacteria increased content of bifidobacteria and lactobacilli. Probably, this is due to the selective effect of the zeolite which has a special microstructure that can restrain pathogenic bacteria.

\section{CONCLUSION}

From these above results, it can be concluded that Chankanay deposit's zeolite dietary treatment of 5\% by weight of the feed showed significant reduction in intestinal counts of E.coli and elevation in intestine Lactobacillus spp. and bifidobacteria counts of chickens compared to control group $(\mathrm{p}<0.05)$. So the feed additive will increase the amount of useful intestinal bacteria, and suppress the growth of the pathogenic microflora.

\section{REFERENCES}

[1] Resolution of the Government of the Republic of Kazakhstan from February 18, 2014 № 103. On approval of Rules of subsidizing of local budgets for the development of livestock breeding, increasing the productivity and quality of livestock products, IS Paragraph 2/28/2014. (in Russian).

[2] V. V. Sorokin, "Normal intestinal microflora of animals," Pticevodstvo, vol. 1, pp. 2-7, 2011 (in Russian).

[3] P. Spiridonov, V. M. Davydov, and A. B. Mal'cev, Non-traditional feed in the diet of birds, Literature review, Omsk, Russia, 2002, p. 223 (in Russian).

[4] S. F. Suhanova, and Ju. A. Karmackih, "The use of bentonite in growing broiler goslings Italian White breed," Rational use of food resources, and the genetic potential of livestock: Coll. scientific. tr. Omsk: Regional Printing House, 2004, pp. 147-151 (in Russian).
[5] V. Truhachev, "Influence "Laktovit $\mathrm{H}$ " on the formation of intestinal microbiota of broiler chickens," Glavnyj zootehnik, vol. 8, pp. 22-24, 2012 (in Russian).

[6] T. Truhina, "Zeolites - effectiveness of raw materials," Pticevodstvo, vol. 9, pp. 32-33, 2007 (in Russian).

[7] M. Ventura, V. Meylan, and R. V. Zink, "Molecular microbiolanalys of Bifidobacterium isolates from different environments by the specices specific amplitied ribosomal restriction analysis," Appl. Environ. Microbiol., vol. 69, pp. 4296-4301, 2003.

[8] M. A. Elliot, and H. M. Edwards, "Comparison of the effects of synthetic and natural zeolite on laying hen and broiler chicken performance", Poultry Science, vol. 10, pp. 2115-2330, 1991.

[9] V. I. Fisinin, The use of natural zeolites in the poultry industry, Methodical recommendations VNITIP: Zagorsk, 1990, p.20 (in Russian).

[10] V. N. Krasnogolovez, "The intestinal disbacteriosis," Medicine, p. 207, 1989.

[11] G. John Holt, R. Noel Krieg, H. A. Peter Sneath, T. James Staley, and T. Williams Stanley, Bergey's Manual of Determinative bacteriology, 9th ed., Moscow: Mir, ch. 1-2, 1997.

[12] C. A. Edwards, and A. M. Parrett, "Intestinal flora during the first months of life: new perspectives," Br. J. Nutr., vol. 88, Suppl. 1, pp. 1117, 2002.

[13] N. V. Pavlova, F. S. Kirzaev, and P. Lapinskajte, "The value of intestinal normal microflora of birds for their organism," H. Zootech., vol. 10, pp. 37-39, 2006.

[14] H. W. Modler, R. C. McKellar, and M. Yagichi, "Bifidobacteria and bifidogenic factors - review," Can. Inst. Food Saci. Technol. J., vol. 23, pp. 29-40, 1990.

[15] Gokce, and J. H. Lakey, "Production of an E. coli toxin protein; colicin A in E.coli using an inducible system," Turk. J. Chem., vol. 27, pp, 323$331,2003$.

[16] C. Riddel, and X. M. Kong, "The influence of diet on necrotic enteritis in broiler chickens," Avian Dis., vol. 36, pp. 500-502, 1992.

[17] D. J. Langhout, "The role of the intestinal flora as affected by NSP in broilers," Proceedings, Twelfth European Symposium on Poultry Nutrition, Veldhoven, The Netherlands, 15-19.08.1999, pp. 203-220, 1999.

[18] J. P. Salanitro, I. G. Blake, and P. A. Muirhead, "Studies of the cecal microflora of commercial broiler chickens," J. Appl. Microbiol., vol. 28, 3, pp. 439-446, 1974.

[19] Yaghobfar, M. Rezaian, M. Ashrafi-Helan, J. Barin, H. Fazaeli, and Sh.Sayed Davod, "The effect of hull-less barley dietary on the activity of gut microflora and morphology small intestinal of layer hens," Pak. $J$. Biol. Sci., vol. 9 (4), pp. 659-665, 2006.

[20] M. G. Wise, and G. R. Siragusa, "Quantitative analysis of the intestinal bacterial community in one- to three-week-old commercially reared broiler chickens fed conventional or antibiotic-free vegetable-based diet," J. Appl. Microbiol., vol. 102, 4, pp. 1139-1148, 2007.

[21] R. D. Milles, R. H. Harms, and S. M. Lourent, "Influence of sodium zeolite of laying hens performance," Nutrition Reports, International, vol. 6, pp. 1098-1102, 1986.

[22] X. Karamanlis, P. Fortomaris, G. Arsenos, I. Dosis, D. Papaioannou, C. Batzios, and A. Kamarianos, "The Effect of a Natural Zeolite (Clinoptilolite) on the Performance of Broiler Chickens and the Quality of Their Litter," Asian Australas. J. Anim. Sci., vol. 11, p. 237, 2008.

[23] Y. Al-Nasser, F. Sameer, E. Abdulameer, K. Al-Saffar Faten, and E. Abdullah Mariam, "Zeolite as a Feed Additive to Reduce Salmonella and Improve Production Performance in Broilers," International Journal of Poultry Science, vol. 6 pp.449-453, 2011.

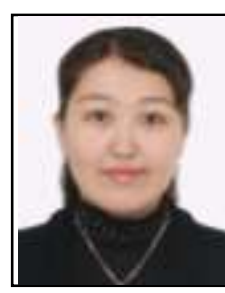

Slyamova Ayana Yerlanovna Kazakhstan, Almaty, 05/02/1988 $\mathrm{PhD}$ student from Kazakh National Agrarian University. Specialty - Veterinary Sanitation. 